\title{
InTERnATIONAL CONFERENCE 'Public FinanCE AND FINANCIAL LAW IN THE FACE OF CHALLENGES OF THE FINANCIAL CRISIS' (WROCLAW, 24-25 OCTOBER 2013)
}

\author{
PATRYCJA ZAWADZKA *
}

This International Conference was organized by the Department of Public Finance Law Department at the Faculty of Law, Administration and Economics at the University of Wroclaw on 24th-25th October 2013 in Wroclaw. The conference was held under the patronage of His Magnificence Rector of the University of Wroclaw Professor Marek Bojarski.

The number of participants amounted to 120, representing 17 Polish research centers and 6 centers from abroad: Austria (University of Salzburg), Belarus (Yanka Kupala State University of Grodno), Czech Republic (Masaryk University in Brno, University of Ostrava), Russia (Moscow State University, Voronezh State University). The conference also attracted representatives of the Regional Chamber of Audit, the Internal Revenue Service and the Tax Audit Office, as well as tax advisors, representatives of local governmental authorities and banks, students and a number of PhD students. The Chairman of the Organizing Committee was Professor Wiesława Miemiec.

The conference was organized with a view to providing a forum for discussing current problems in public finance and public finance law caused by the economic crisis which began in Europe in 2008 on a large scale, severely afflicting affecting many markets and diverse institutions. The multidimensional nature of the financial slump exposed many weaknesses in public law regulations. The global nature of this disturbing development has created a platform for interdisciplinary discussion with no limitations on individual states' problems. Five years from the beginning of the crisis in Europe, there was a sufficient period of time to evaluate regulations that minimized the effects of the crisis and to prevent future similar situations. The aim of the conference was to create conditions which could enable people involved in the academic and practical issues of public finance and

DOI: $10.2478 /$ wrlae-2014-0107

* PhD; LLM; Department of Financial Law, University of Wroclaw. p.zawadzka@prawo.uni.wroc.pl 
public finance law to exchange their ideas and experiences. Recent amendments to the law and new proposals were also discussed.

The Conference was inaugurated at Leopoldinum Hall, which boasts a unique, late baroque glamour style at the University of Wrocław, by His Magnificence Vice-Rector of the University of Wrocław Professor Adam Jezierski, the Dean of the Faculty of Law, Administration and Economics Professor Włodzimierz Gromski, and the Head of the Public Finance Law Department - Professor Wiesława Miemiec.

The inaugural lecture was given by Professor Teresa DębowskaRomanowska, a judge of the Constitutional Court in Poland, who presented the problems associated with spending and raising public funds in times of crisis comprehensively.

Thereafter, the conference was divided into in three sessions of four thematic seminars.

The first session was held in the morning of Thursday 24th October 2013 and comprised three seminars. The first seminar on 'Public Revenue' was chaired by Professor Bogumił Brzeziński. The main problem discussed during this seminar concerned taxes. Professor Sabine Urnik and Elisabeth Steinhauser, MA (Faculty of Social and Economic Sciences, University of Salzburg, Austria) gave a presentation called 'Management through taxes. Selected instruments of management through taxes in Austria', showing that the Austrian legislature has exerted a managing influence, particularly on income tax, through a variety of regulations during the current economic and socio-political state crisis. It is permissible in this context to use taxation as a management tool for active government social and economic policy, with the objective of raising public welfare under the terms of constitutional law, both in general and in specific instances.

Professor Witold Modzelewski (Faculty of Law and Administration, University of Warsaw) characterized actual problems of the application of tax law in his speech 'Pathologies and Anomalies of Value Added Tax', sharing his experiences in the profession of a tax adviser with a strong emphasis on practical aspects. Professor Dominik Mączyński (Faculty of Law and Administration, Adam Mickiewicz University in Poznań) delivered a presentation on the influence of determinations made during criminal proceedings on decisions concerning value added tax. In a speech entitled 'Criteria for Differentiation of Local Self-Government Revenue Types', assistant professor Monika Bogucka - Felczak (Faculty of Law and Administration, University of Łódź) considered current problems of transfer income in detail. Their speeches provided a wide variety of practical insights.

The second seminar, 'Rationalization of public expenditures', was coordinated by Professor Krystyna Sawicka and it focused on spending public money. Assistant professor Aleksey Paul (The Voronezh State University, Russia) presented a paper on 'Russian Budget Law and the Financial Crisis'. He indicated and discussed the high dependence of the Russian economy on exports of natural resources and the level of development of the banking sector in Russia. Professor Krystyna Piotrowska-Marczak (Torun School of Banking, Poland) analyzed the ambiguity of the concept of the rationalization of public expenditures. Professor stressed that decisions establishing a spending cuts without 
considering the consequences may result in the reduction of the investment in many areas of our life, e.g. higher education, cooperation with foreign universities or academic sport. The next paper was delivered by Professor Andrzej Niezgoda (Faculty of Law and Administration, Marie CurieSkłodowska University in Lublin) who focused on budget deficit and the capacity of local government units to provide public services. To a large extent, limitations to the budget deficit of the local government are directly linked to the general situation of the public finance sector, which is determined by the budget deficit and State Treasury debts. The state budget limits do not refer adequately to the situation of a particular municipality, county or province. This makes it difficult for local governments to find necessary resources in order to realize public tasks assigned to them. Jana Kranecová, MA (Faculty of Law, Masaryk University, Brno, Czech Republic) presented legal tools of financial management and introduced tools, planning and reporting which are permissible under the current legislation of the Czech Republic. Mrs Kranecová stressed that the mediumterm plan (the outlook of the budgets of territorial authorities) should be based on defined development strategies of government units, which must involve the strategy and strategic management of public services that local government units provide for their citizens.

The third seminar, 'State budget law and local government. Public debt', was moderated by Professor Marek Mazurkiewicz. The first speaker was assistant professor Lilia Bobkova (The Voronezh State University, Russia), who focused on political aspects in the budget legislation of the Russian Federation during the period of globalization and development. The next speaker Professor Janusz Stankiewicz (Faculty of Law, University of Białystok) analyzed the legal aspects of the application of multi-year financial planning tools in Poland and stated that this plan serves as a useful auxiliary tool of the government, allowing it to analyze and forecast the financial situation of the state public sector. Next, Professor Ryszard Sowiński (Faculty of Law and Administration, Adam Mickiewicz University in Poznań) presented his paper on managerial theory and practice. Assistant professor Urszula Zawadzka-Pąk (Faculty of Law, University of Białystok) analyzed legal tools for balancing public finances as a lesson for Poland, based on the experiences of France, and emphasized that the French experience shows that the same basic plan of public finances in the act does not guarantee compliance with the provisions contained therein.

The Second Session took place in the afternoon of 25th October 2013. The first seminar, 'Public revenue', was moderated by Professor Witold Modzelewski. The first paper was given by Professor Lila Abramchik (Yanka Kupala State University of Grodno, Belarus) who explained the main ideas behind the reform of tax regulations in Belarus as a means of limiting the budget deficit. Professor L. Abramchik has remarked that the effectiveness of the tax system results from the efficient administration of tax to a large extent. Professor Henryk Dzwonkowski (Faculty of Law and Administration, University of Lódź) discussed the status of the tax remitter's activity in the context of tax law. Subsequently, Professor Marek Zdebel (Faculty of Law and Administration, University of 
Silesia in Katowice) considered the rationalization of the tax system and the rationalization of tax credits in payments. The next speech was given by Professor Petr Mrkývka (Faculty of Law, Masaryk University, Brno, Czech Republic), who had a very interesting presentation about tax administration reform in the Czech Republic. Professor Petr Mrkývka referred to Polish regulations and compared them. Assistant professor Wojciech Gonet (Warsaw School of Economics) focused on current problems of the rationalization of public revenue. Kristýna Müllerová, MA (Faculty of Law, Masaryk University, Brno, Czech Republic) focused on the responsibility of 'minor taxpayers' in paying local taxes in Czech law.

The third seminar, 'State budget law and local government. Public debt', was chaired by Professor Wiesława Miemiec. Professor Zbigniew Ofiarski and Professor Małgorzata Ofiarska (Faculty of Law and Administration, University of Szczecin) prepared a paper that evaluated the rules for providing financial assistance as a special form of cooperation between local government bodies in performing public services. Assistant professor Marcin Tyniewicki (Faculty of Law and Administration, University of Bialystok) focused on the multiannual financial planning in EU Member States, especially with regard to current trends and perspectives, and also from the point of view of the Council's Directive 2011/85/EU of November 2011 on requirements for budgetary frameworks of the member states. Assistant professor Monika Kępa (Faculty of Law and Administration, Maria Curie-Skłodowska University in Lublin) concentrated on the State Budget and Multiannual Financial Plan - de lege ferenda and de lege lata considerations. Assistant professor Małgorzata Gałecka (University of Economics in Wrocław) discussed changes to the budgets of local government bodies and their effect on long-term financial forecasts. Michal Koziel, MA (University of Ostrava, Czech Republic) dealt with new methods for limiting public debt in the Czech Republic. Assistant professor Anzelika Krastsina (Yanka Kupala State University of Grodno, Belarus) prepared a presentation about the dominion of local government and its determination in the budget act.

The third session was held on Friday 25th October 2013 and included seminar entitled 'Financial markets' supervised by Professor Zbigniew Ofiarski. Assistant professor Diana Cibulskiene (Šiauliai University, Faculty of Social Sciences, Lithuania) focused on the impact of economic cycles on the stock market in EU countries. Professor Anna Jurkowska-Zeidler (Faculty of Law and Administration, University of Gdańsk) presented the Banking Union as an institutional safeguard of financial stability in the euro zone. The debt crisis in the euro area clearly showed that financial stability cannot be effectively managed at the national level, due to the negative relationship between governments and banks. Professor Tomasz Nieborak (Faculty of Law and Administration, Adam Mickiewicz University in Poznań) gave a speech on creating and applying financial market law in the context of the behavioral theory of law. He looked closely at the phenomenon of the so-called 'run on the banking market', the knock-out effect, the contagion effect or moral hazards, and argued that each of them is a huge threat to a stable and efficient financial system. Professor Andrzej Gorgol (Faculty of Law and Administration, Maria Curie-Skłodowska University in Lublin) discussed currency law tools 
of protection for financial markets. The Professor emphasized that the extensive catalogue of legal tools of foreign exchange can be used to protect the financial market and its regulation. Assistant professor Magdalena Mosionek-Schweda (Faculty of Economics, University of Gdańsk) and assistant professor Przemysław Panfil (Faculty of Law and Administration, University of Gdańsk) were co-authors of a paper on the collective action clause in the euro zone. Assistant professor Michal Janovec (Faculty of Law, Masaryk University Brno, Czech Republic) focused on the current integration of supervision of the financial markets and who is responsible for such supervision. It is the local supervisory authority, not the central authority, which has greater flexibility and knowledge of the local situation of the financial market in the pan-European context.

The conference was a forum for the exchange of opinions, observations and views, resulting not only in the publication of academic papers, but also providing inspiration for the future. The reflections resulted from the conference will be published under the title 'Public Finance Institutions Under the Conditions of Economic Crisis' under the editorship W. Miemiec, K. Sawicka by Wolters Kluwer in 2014. 